\title{
Specific epithet - a noun in the genitive case
}

Iliana Ilieva

University of Forestry, Sofia, Bulgaria

Corresponding Author: Iliana Ilieva. AGH - University of Forestry, Sofia, Bulgaria.

Received date: October 30, 2020; Accepted date: November 04, 2020; Published date: November 17, 2020

Citation: Iliana Ilieva (2020) Specific epithet - a noun in the genitive case J, Biotech. and Bioproc. 1(2); DOI: 10.31579/2766-2314/009

Copyright: () 2020, Iliana Ilieva, This is an open access article distributed under the Creative Commons Attribution License, which permits unrestricted use, distribution, and reproduction in any medium, provided the original work is properly cited.

\begin{abstract}
The current article is included in the larger research "The linguistic structure of binomial botanical denominations- specific epithet", based on "Conspectus of the Bulgarian vascular flora", fourth revised and updated edition, Sofia, 2012, and deals with a less common type of specific epithets nouns in the genitive case. The epithets are organized alphabetically in several groups according to their semantic.
\end{abstract}

Keywords: specific botanical epithets; the genitive case; botanical nomenclature

\section{Introduction}

In accordance with the ICBN (International Code of Botanical Nomenclature): "The name of a species is a binary combination consisting of the name of the genus followed by a single specific epithet in the form of an adjective, a noun in the genitive, or a word in apposition, or several words, but not a phrase name of one or more descriptive nouns and associated adjectives in the ablative" (Chapter III, Section 4, Article 23.1).

The article discusses a less common type of specific name - a noun in the genitive. Such epithets are expressed by nouns in the genitive singular or the genitive plural. The current edition describes roughly 40 binomial denominations containing this type of specific epithet. The epithets are arranged alphabetically in their genitive form as they are used in each binomial denomination; the literal meaning and the basic forms of the lexeme are also provided.

A list of the plant species containing each particular specific epithet is provided together with their Common English name. When a species is found in official literary sources only with scientific name in Latin, such name is referred to as Accepted name. The names that have not yet been officially accepted due to the lack of enough arguments whether the name should be treated as accepted or not are designated as unresolved name.

Several categories of epithets can be differentiated according to their meaning:

I. Geographical denominations - names of countries, settlements, mountains, rivers and other geographic objects.

Note: The epithets from this group are also represented in Iliana Ilieva. Specific Epithet-A Denomination of Geographical Region, Particular Place of Growth, Spread or Origin of the Plants. Biomed J Sci \& TechRes 24(5)-2020. BJSTR. MS.ID.004126.

1. caliacrae - Gen. sg. (Caliacra, ae $f$ - Kaliakra, a long and narrow cape on the northern Bulgarian Black Sea Coast).

- Alyssum caliacrae (Accepted name)
- Centaurea caliacrae (Accepted name; literally: Caliacra knapweed)

- $\quad$ Silene caliacrae (Accepted name; literally: Caliacra catchfly; Bulgarian endemic)

2. diampolis - Gen. sg. (Diampolis, is $f$ - an ancient name of Yambol, a city in Southeastern Bulgaria).

- Colchicum diampolis (synonym of Colchicum szovitsii)

3. klisurae - Gen. sg. (Klisura, ae $f-$ a small town in Central Bulgaria).

- Hieracium klisurae (Accepted name)

4. lapponum - Gen. pl. (Lappones, um $m$ - the inhabitants of Lapponia, a mountainous area in Lapland, North Sweden). In this case, the place of distribution or origin of the species is indicated by ethnonym.

- Salix lapponum (Downy willow)

5. nigrimontium - Gen. pl. (Nigrimontes, ium $m$-Montenegro, a country in Southeast Europe on the Adriatic Sea Coast).

- Herniaria nigrimontium (Accepted name)

6. ravennae - Gen. sg. (Ravenna, ae $f-$ the main city of the Province of Ravenna, in the Emilia-Romagna region of Northern Italy).

- Erianthus ravennae (Ravenna grass, Plume grass)

7. slaviankae / slavjankae - Gen. sg. (Slavjanka, ae $f-$ Slavyanka, formerly known as Alibotush, from Turkish Alibotuş, and Kitka Planina, from Bulgarian Китка планина, is a mountain located on the border of Southwestern Bulgaria and Northernmost Greece).

- Pulsatilla slaviankae (Unresolved name; Balkan endemic) The record derives from WCSP (in review) (data supplied on 2012-03-23) which does not establish this name either as an accepted name or as a synonym with original publication details: in Fl. Reipubl. Popul. Bulgar. 4: 1111970.

- Erysimum slavjankae (Accepted name) 
8. $\quad$ strymonis - Gen. sg. (Strymo (n), onis $m$ - an ancient name of the Struma river, in the territory of Bulgaria and Greece).

- $\quad$ Dianthus strymonis (Accepted name)

9. tekirae - Gen. sg. (Tekira, ae $f$ - an obsolete name of the village Trivoditsi in Central South Bulgaria).

- Gypsophila tekirae (synonym of Gypsophila perfoliata Perfoliate baby's-breath)

II. Plant names - occurring predominantly as a specific epithet in parasitic species to denote the host (Cuscuta trifolii, Orobanche esulae etc.), rarely signify similarity (Adenostyles alliariae).

10. alliariae - Gen. sg. (Alliaria, ae $f-$ a genus of flowering plants in the mustard family Brassicaceae; the name is derivative from allium garlic, due to the particular smell of the crumpled leaves of this plant).

- Adenostyles alliariae (Hedge-leaved adenostyle; the specific epithet refers to the similarity of the leaves of those of Alliaria.)

11. carvi - Gen. sg. (carvum, i $n$ - an old name of caraway; probably originated from the Latinized name Caria - an ancient region of Asia Minor in Southwestern Turkey).

- Carum carvi (Caraway, Meridian fennel)

12 esulae - Gen. sg. (esula, ae $f$ - a Latinized form of a Celtic name of a type of spurge).

- $\quad$ Orobanche esulae (Accepted name)

13. othonnae-Gen. sg. (Othonna, ae $f$-a genus of African origin in the sunflower family Asteraceae).

- Senecio othonnae (synonym of Jacobaea othonnae)

14. oxycedri - Gen. sg. (Oxycedrus, i $f$ - plant genus with leaves like those of cedar, but sharp).

- Arceuthobium oxycedri (Juniper dwarf mistletoe)

15. picridis - Gen. sg. (Picris, idis $f$-oxtongue: a genus in the sunflower family Asteraceae described as a genus by Linnaeus in 1753).

- Orobanche picridis (Oxtongue broomrape)

16. sisarum - Gen. pl. (Sisa, ae $f$ - vernacular name in Peruvian Amazonia relating to the species of Arrabidaea in the family Bignoniaceae).

- $\quad$ Sium sisarum (Skirret)

17. teucrii - Gen. sg. (Teucrium, i $n$-a genus of mostly perennial plants in the family Lamiaceae commonly known as germander). The plant is cited by Dioscorides and Pliny the

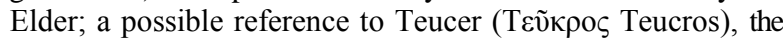
first king of the Troas who lived before the Trojan War who, according to legend, used plants of this genus for medicinal purposes.

- Orobanche teucrii (Germander broomrape - the specific epithet designates the host of these parasitic herbaceous plants broomrape Orobanche)

18. trifolii-Gen. sg. (Trifolium, i $n$-clover, trefoil).

- Cuscuta trifolii (synonym of Cuscuta epithymum - Clover dodder: the clover is the host plant for parasitic dodder Cuscuta)

\section{Denominations indicating peculiarities or} practical plant application

19. avium - Gen. pl. (avis, is $f$-bird).

- Prunus avium (Wild cherry, Sweet cherry, Gean; literally: of the birds, because of the fruits which are birds' favourite food)

20. carthusianorum - Gen. pl. (carthusiani, orum $\mathrm{m}$ - the monks of the Carthusian order, founded in the 11th century in the Chartreuse Valley in the French Alps near Grenoble)
- Dianthus carthusianorum (Carthusian pink)

21. columnae-Gen. sg. (columna, ae $f$-column, pillar). Note: Another possible interpretation of this epithet refers to the Neapolitan botanist Fabio Colonna (Fabius Columna, 1567-1640), author of Phytobasanos (Torture of plants), 1592.

- Aubrieta columnae (Accepted name; Bulgarian endemic)

- Scutellaria columnae (Accepted name)

22 fullonum - Gen. pl. (fullo, onis $m$-fuller)

- Dipsacus fullonum (Wild teasel, Fuller's teasel: because of the prickly stems and leaves used to teasel linen and wool)

23. officinarum - Gen. pl. (officina, ae $f$-medieval laboratory: due to the use in pharmaceutics, herbal medicine, liquor production, perfumery and the like).

- Ceterah officinarum (Rustyback, literally „Officinal fern" because is used as a medicinal plant)

24. tinctorum - Gen. pl. (tinctor, oris $m$-dyer: because these plants were used to dye fabrics).

- $\quad$ Rubia tinctorum (Common madder, Dyer's madder)

IV. Denominations meaning area of spread - nouns in the genitive plural. The suffix -etum, noting the place of growth, is often used.

25. deorum - Gen. pl. (deus, i $m$-god, deity). The epithet is associated with Musala - the highest peak in Rila Mountain, meaning "near God" or "God's Mountain" (from Arabic through Ottoman Turkish).

- $\quad$ Primula deorum (Rila primrose, Rila cowslip, God's cowslip)

26. dumetorum - Gen. pl. (dumetum, i $n$ - a thicket; growing in thickets of thorn-bushes).

- Bilderdykia dumetorum (synonym of Fallopia dumetorum - Copse bindweed)

- $\quad$ Vicia dumetorum (Great wood-vetch)

27. ericetorum - Gen. pl. (ericetum, i $n$ - soil colonized by heather; growing among the heather).

- $\quad$ Carex ericetorum (Rare spring-sedge)

28. nemorum - Gen. pl. (nemus, oris $n$ - forest, wood; of the woods, relating to woodland species).

- $\quad$ Stellaria nemorum (Wood stitchwort)

29. pinetorum - Gen. pl. (pinetum, i $n$ - pine forest).

- $\quad$ Orchis pinetorum (synonym of Orchis mascula - Early purple orchid)

30. sepium - Gen. pl. (s(a)epes, is $f$-hedge, fence: referred to plants that prefer hedges as a growing place).

- $\quad$ Calystegia sepium (Hedge bindweed)

- Vicia sepium (Bush vetch)

31. tectorum - Gen. pl. (tectum, i $n$-roof: for plants growing on the roofs).

- $\quad$ Bromus tectorum (Drooping brome, Cheatgrass)

- Crepis tectorum (Narrowleaf hawksbeard)

\section{Miscellaneous}

32 sophiae-Gen. sg. (sophia, ae $f$-wisdom, sapience). - Taraxacum sophiae (Accepted name)

33. trionum - Gen. pl. (Triones, um $\mathrm{m}$ - the constellations of the two Bears. From "septem triones" originates the term "septentrionalis" - northern, so "trionum" can be understood as a reference to the north, northern).

- Hibiscus trionum (Flower-of-an-hour, Bladder hibiscus) 
34. veris - Gen. sg. (ver, veris $n$ - spring).

- $\quad$ Primula veris (Cowslip, Cowslip primrose, Common cowslip)

\section{Conclusion}

The specific epithets expressed by nouns in the genitive as well as the other types of specific epithets represent an integral part of the binomial botanical names. Despite their relatively rare use, they carry a variety of information about the peculiarities, habitat and practical application of plants. Good knowledge of these epithets contributes to the thorough and comprehensive knowledge of the species themselves and confirms Carl Linnaeus' thought "Nomina si nescis, perit et cognitio rerum" (If you know not the names of things, the knowledge of things themselves perishes)

\section{References}

1. Assyov B, Petrova A, Dimitrov D, Vassilev R (2012) Conspectus of the Bulgarian vascular flora: Distribution maps and floristic elements. Fourth revised and enlarged edition. Sofia, BSBCP.

2. Brummit RK, Powel C (Eds.) (1992) Authors of plant names. Royal Botanic Gardens, Kew, UK, pp. 732.

3. Brummit RK (Eds.) (1992) Vascular plant families and genera. Royal Botanic Gardens, Kew, UK, pp. 804.

4. Castiglioni L, Mariotti S (2007) Vocabolario della Lingua Latina. Loescher Editore-Quarta edizione, Torino pp. 2272.

5. Clifford H, Trevor, Bostock, Peter D (2007) Etymological Dictionary of Grasses. Springer-Verlag, Berlin Heidelberg, pp. 319.

6. Dvoreckij IH (1996) Latinsko-russkij slovar'. Russkij yazyk Moskva, pp. 845.

7. Giamello G (1004) Dizionario botanico. Sorì Edizioni, Piobesi d'Alba, pp. 115.
8. Glare P GW (1982) Oxford Latin Dictionary. Glarendon Press, Oxford, UK, pp. 2126.

9. Kaniskov V (2015) Botanicheski rechnik. Izd. Duo-V "OOD, S. Sofia pp. 697.

10. Kirpichnikov M, Zabinkova NN (1977) Russko-latinskij slovar' dlya botanikov. Izd-o, Nauka”, Leningrad pp. 856.

11. Kitanov B (1994) Botanicheski rechnik. Izd-vo Petar Beron, Sofia, pp. 144.

12. Kozhuharov S (red.) (1982) Flora na NR Balgaria. T. VIII. Izd. BAN, Sofia, pp. 520.

13. Kozhuharov S (red.) (1995) Flora na Republika Balgaria. T. X. Izd. BAN, Sofia, pp. 431.

14. Kuzmanov B (red.) (1989) Flora na NR Balgaria. T. IX Izd. BAN, Sofia, pp. 541.

15. Kuzmanov B (red.) (1979) Flora na NR Balgaria. T. VII. Izd. BAN, Sofia, pp. 530.

16. Peev D (red.) (2012) Flora na Republika Balgaria. T. XI. Izd. BAN, Sofia, pp. 525.

17. Peev D (red.) (2015) Chervena kniga na Republika Balgaria. T. 1. Rastenia i gabi. IBEI - BAN \& MOSV, Sofia, pp. 887.

18. Yordanov D (red.) (1976) Flora na NR Balgaria. T. VI. Izd. BAN, Sofia, pp. 592.

19. Yordanov D (red.) (1963) Flora na NR Balgaria. T. I. Izd. BAN, Sofia, pp. 509.

20. Yordanov D (red.) (1964) Flora na NR Balgaria. T. II Izd. BAN, Sofia, pp. 426.

21. Yordanov D (red.) (1966) Flora na NR Balgaria. T. III. Izd. BAN, Sofia, pp. 638.

22. Yordanov D (red.) (1970) Flora na NR Balgaria. T. IV. Izd. BAN, Sofia, pp. 748.

23. Yordanov D (red.) (1973) Flora na NR Balgaria. T. V. Izd. BAN, Sofia, pp. 444.

24. Zander R (2014) Dictionary Plant Names. Plant Press. (19 ${ }^{\text {th }}$ Edn.), pp. 990. 